\title{
Analysis of Ganja Chemical Content (Cannabis Sativa L.) Discussion Results in the Aceh Regional Police Region Using the GC-MS Method
}

\author{
Ungkap Siahaan $^{1}$ \\ Chemistry Magister Program \\ Of the Universitas Sumatera Utara \\ Medan, Indonesia \\ hinalang_siahaan@yahoo.co.id
}

\author{
Harlem Marpaung ${ }^{2}$, Tamrin ${ }^{2}$ \\ Lecturers at Chemistry Department \\ Of the Universitas Sumatera Utara \\ Medan, Indonesia \\ harlem_marpaung@yahoo.com \\ thamrinsumut@gmail.com
}

\begin{abstract}
Cannabis (Cannabissativa L.) is an annual plant, which can grow and spread in tropical or sub-tropical regions with a height of one to five meters (Emcdda, 2015). Human selection is done for various uses and climate-influenced natural selection produces various varieties and chemical compositions. Analysis of the chemical content of cannabis (Cannabis sativa L) as a result of confiscation in the Aceh Regional Police, namely Lhokseumawe Regional Police, Pidie Regional Police, East Aceh Regional Police (Idi Rayeuk), Benar Meriah Regional Police and Central Aceh Regional Police (Takengon) were conducted by GC-MS method. Cannabis was extracted with n-hexane and marijuana extract was analyzed by GC-MS. $\triangle 9$-THC and CBC compounds were found in all marijuana samples, CBN was found in 4 origin areas except Central Aceh Police Station, 2-Metoxy-5-isopropilaxy-7-propenylnaphthquinone was found in two police stations from Pidie Police and Central Aceh District Police. The biggest concentration of $\triangle 9$-THC is $80.92 \%$ of the East Aceh Police Station; $\triangle 9$-THCV is from two original police stations, namely East Aceh Police and Benar Meriah Police; CBN is the biggest 14.25\% of Polres Benar Meriah; The biggest CBC is 10.98 from the East Aceh District Police.
\end{abstract}

Keywords- Cannabis, CBN, CBD and $\triangle 9-T H C$.

$* * * * *$

\section{INTRODUCTION}

Efforts to emphasize world drug abuse through the UNODC institution aim to make the world safer from crime, drugs, and terrorism. To be effective and sustainable, responses to these threats must include strategies covering various fields such as crime prevention, criminal justice reform and justice for childre [1]. The Indonesian government through the National Narcotics Agency (BNN) and the Republic of Indonesia Police (POLRI) is a professional nonministerial institution capable of mobilizing all components of society, nation and state of Indonesia in implementing prevention and eradication of illicit drug trafficking, narcotics, precursors and addictive ingredients others in all regions of Indonesia (BNN Republic of Indonesia. 2015).

The National Police Lab is one of the laboratories authorized by the Government of the Republic of Indonesia through Republic of Indonesia Law No. 35 of 2009 concerning narcotics and the Decree of the Minister of Health of the Republic of Indonesia Number 194/Menkes/SK/VI/2012 concerning the appointment of narcotics and psychotropic examination laboratories to examine marijuana evidence at the qualitative and quantitative level (Minister of Health of the Republic of Indonesia 2014). According to data from the Directorate of Drug Narcotics of the Aceh Regional Police (Direktorat Reserse Narcotics of Aceh Regional Police), drug cases that occurred in 2016 amounted to 1,444 cases, which in
2017 increased to 1,562 cases. The number of suspects was 2,152 consisting of 2,061 men and 92 women, the secured evidence was 15,886, 6 kilograms of marijuana, 44,975.74 grams of Savu and 3,813 1/2 ecstasy items. Meanwhile, the marijuana fields that were revealed were 103 hectares of land with a total of 486,000 marijuana stems, of which 484,720 stems were immediately facilitated on location by burning up. The marijuana stem samples were secured as evidence of 1,280 stems [2].

Investigation Description of Analysis of Marijuana Evidence of Illicit Circulation of Narcotics in the Legal Area of the East Java Regional Police with the Gas Chromatography-Mass Spectrometry Method (GC-MS) was carried out by processing GC-MS Chromatogram data and analyzing data using Principal Component Analysis (PCA) with Software Camo-unscramble sofware version 9.8 and generated patterns of distribution of marijuana evidence into 3 groups including I: Pacitan City, Trenggalek, Lamongan, Mojokerto, Lumajang, Bondowoso, Situbondo, and Pamekasan have similar components of chemical compounds, II: Gresik City, Surabaya, Sidoarjo, Pasuruan , Probolinggo, Jember, Banyuwangi, Malang, Blitar, Tulungagung, Kediri, and Bojonegoro have similarities in chemical compound components and III: Madiun, Nganjuk, Kediri, Bangkalan, and Pasuruan cities have similar components of chemical compounds [3]. 
Systematic evaluations of the potential of growing cannabis plants in Albania have been carried out. The marijuana samples used came from different regions and were analyzed using the GC-MS method. The results showed the concentration of $\triangle 9$-THC was different in each growing region and the greatest concentration was found in marijuana flowers [4].

\section{EXPERIMENTAL}

\section{A. General}

Cannabis can cause euphoria, relaxation, and feeling healthy. Cannabis does not cause dangerous addiction, but at least mild degrees of dependence can occur. Cannabis can cause acute psychotoxic effects which in some ways resemble "bad trip" due to LSD [5].

The effect caused depends on the amount and how to use it. In the short term, it can cause feelings of relaxation, comfort and well-being, increased visual and auditory perceptions, lots of speech, a feeling of confusion and emotion decreasing memory ability, driving ability, and coordination. In cases of hallucinations are rare. On use with smoking, the effect will appear in one to three hours [6]. Whereas if eaten, the effect will appear 12 hours later. Death due to temporary overdose is unknown. The effects on long-term use can increase the risk of bronchitis, lung cancer, lethargy, being indifferent, neglecting work. The effects of using marijuana can also lower blood pressure and increase heart rate, so it is very dangerous when used by people who have heart disorders. The use of marijuana can reduce male and female fertility, and if used during pregnancy can cause premature birth (British Medical Association, 2005) [7].

The heaviest effect of marijuana is in the brain. Brain damage that occurs is irreversible or irreversible damage. The effect of marijuana in the brain depends on the length, amount and method of use. The effect that occurs is euphoria, feeling relaxed, drowsiness and reduced social interaction. In cases of poisoning (use in very large amounts) can arise excessive suspicion (paranoid), visual hallucinations [8], [9] and [10]. Cannabis can increase the effect of sedation on the central nervous system when used together with drugs that have sedative effects, such as anti-anxiety drugs, sleeping pills, anesthetic drugs, narcotics, analgesics, antipsychoses, antidepressants, antihistamines and alcohol (British Medical Association, 2005).

\section{B. Equipment}

Equipments used in this experiment include GC-MS. The GC-MS was used for comparison of samples from different areas of the Aceh Regional Police, Indonesia.

\section{MATERIALS}

Cannabis has psychoactive chemical constituents such as $\Delta$ 9-Tetrahydrocannabinol ( $\Delta 9$-THC). Cannabis is considered to have low toxicity and has the potential to be misused so that it disrupts human health. $\triangle 9$-THC becomes active if in the form of smoke [11].

\section{A. Tools}

- Instrument GC-MS Agilent 7890 A and 5975 Mass Selective Detector, with capillary column DB 5Hi (30 $\mathrm{mm} ; 250 \mu \mathrm{m} ; 0,1 \mu \mathrm{m})$.

- Hamilton Syringe $10 \mu 1$.

- Mattler Toledo Analytical Scales

- Fisher Thermo Scientific vortex.

- EBA 20 Hettich Zentrifugel.

- Glass vial

- Glassware device

- Whatman filter paper 42

- Blender.

\section{B. Material}

- The sample in this study was taken from the evidence of confiscation from the 5 (five) Aceh Regional Police areas, namely: Pidie Regional Police, Lhokseumawe Regional Police, East Aceh Regional Police, Benar Meriah Police, and Central Aceh Police (Takengon).

- N-Heksan p.a (merck).

- Helium Gas

\section{Sample Preparation}

The dried marijuana samples from the fields were smoothed and then weighed 1 gram (Hypergeometric sampling, UN 1998), extracted with $10 \mathrm{ml} \mathrm{n}$-hexane solvent, by means of cortex for 15 minutes at room temperature, then filtered using filter paper (UNODC, 2009). The extracts were centrifuged at $13,000 \mathrm{rpm}$ for 5 minutes and the liquid was ready to be injected into the GC-MS instrument.

\section{Sample Analysis with GC-MS}

Before the analysis is carried out, optimization of the conditions is carried out to obtain a chromatogram with peaks that are both reproducible and separate well (resolution>1) [12]. Some of the optimized conditions of analysis include split ratio, gas flow rate as the flow rate, inlet (injection port) temperature and oven temperature program are as follows:
- Column $0.1 \mu \mathrm{m})$;
- Carrier Gas
- Flow Rate
- Velocity
- Split Flow
- Temperature Settings
: HI 5 DB capillary $(30 \mathrm{~mm} ; 250 \mu \mathrm{m}$
Helium $(\mathrm{He})$
: $0.9 \mathrm{~mL} / \mathrm{min}$;
: $34,567 \mathrm{~cm} / \mathrm{sec}$
: $0.9 \mathrm{~mL} / \mathrm{min}$; 


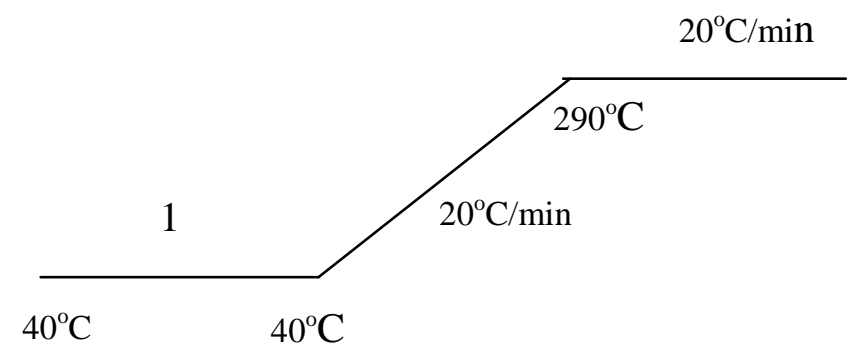

\section{E. Data Analysis}

Cannabis sample extract was injected into GC-MS with optimal conditions. Identity of compounds with certain $\mathrm{m} / \mathrm{e}$, compared with using a data base chromatogram found in the Agilent $7890 \mathrm{~A}$ and 5975MSD instruments [13]. The data base used is the Willey 14 N11 data base spectrum. L.

\section{RESULT}

The results of the GC-MS analysis of the sample were obtained from the Aceh Regional Police of Indonesia, are as follows:

\section{A. The Results of the GC-MS Analysis of Cannabis Samples from the Piddie District}

Police Station produced a chromatogram showing 5 (five) peaks of the compound. The peak with RT 5.819 minutes with molecular weight 314 and molecular formula $\mathrm{C} 21 \mathrm{H} 30 \mathrm{O} 2$ at $76.02 \%$ with Quality 98 concluded as Dronabinol (DELTA-9Tetrahidro cannabinol or $\triangle 9$-THC).

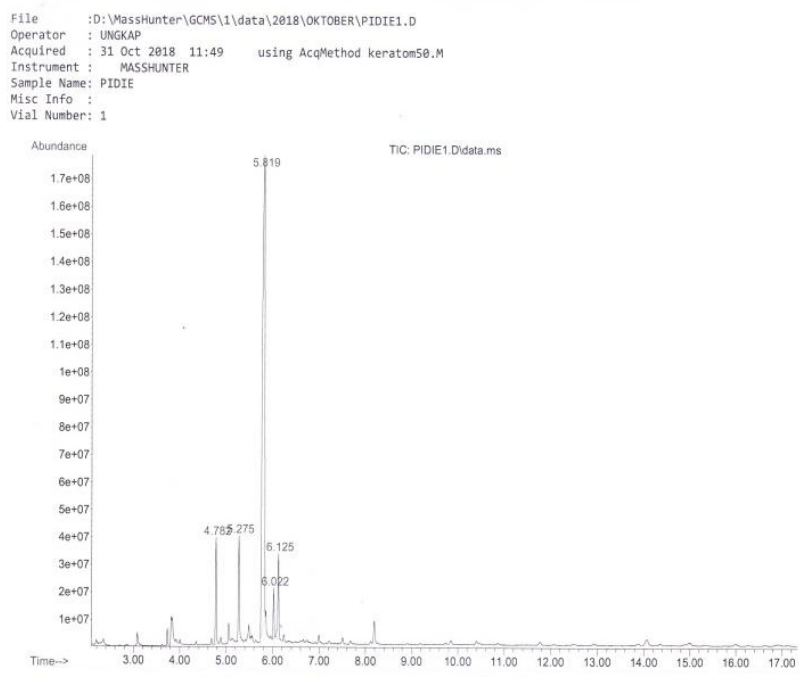

Figure 1. Chromatogram Samples of Marijuana from the Pidie District Police Station.

The table for the results of GC analysis of cannabis samples from the Pidie Police area is shown in the table below.
TABLE 1. THE CHEMICAL CONTENT OF CANNABIS SAMPLES WAS ANALYZED BY GC-MS FROM THE PIDIE DISTRICT POLICE STATION.

\begin{tabular}{|c|c|c|c|c|c|c|}
\hline $\begin{array}{c}\text { No } \\
\text {. }\end{array}$ & $\begin{array}{c}\text { Retentio } \\
\text { n Time } \\
\text { (RT) }\end{array}$ & $\begin{array}{c}\text { Content } \\
\text { (Area } \\
\%)\end{array}$ & $\begin{array}{l}\text { Formula } \\
\text { Molecular }\end{array}$ & $\begin{array}{l}\text { Weight of } \\
\text { Molecular }\end{array}$ & $\begin{array}{l}\text { Chemical } \\
\text { Compounds }\end{array}$ & $\begin{array}{c}\text { Qualit } \\
\text { y }\end{array}$ \\
\hline 1. & 4, 782 & 6,77 & $\mathrm{C}_{27} \mathrm{H}_{20} \mathrm{O}_{4}$ & 288 & $\begin{array}{l}\text { 2-Metoxy-5- } \\
\text { isopropiloxy- } \\
7- \\
\text { propenilnapth } \\
\text { quinone }\end{array}$ & 98 \\
\hline 2. & 5,275 & 7,70 & $\mathrm{C}_{21} \mathrm{H}_{30} \mathrm{O}_{2}$ & 314 & $\begin{array}{c}\text { Cannabicrom } \\
\text { ene }\end{array}$ & 96 \\
\hline 3. & 5,819 & 76,02 & $\mathrm{C}_{21} \mathrm{H}_{30} \mathrm{O}_{2}$ & 314 & $\Delta 9-\mathrm{THC}$ & 98 \\
\hline 4. & 6,022 & 2,97 & $\mathrm{C}_{21} \mathrm{H}_{32} \mathrm{O}_{2}$ & 316 & $\begin{array}{c}\text { 1,3-Diol, 2- } \\
\text { (3,7-dimetl- } \\
\text { 2,6- } \\
\text { octadienil) -5- } \\
\text { pentil } \\
\text { Benzena } \\
\end{array}$ & 99 \\
\hline 5. & 6,125 & 6,54 & $\mathrm{C}_{21} \mathrm{H}_{26} \mathrm{O}_{2}$ & 310 & CBN & 99 \\
\hline
\end{tabular}

B. Results of Marijuana Analysis with GC-MS from the Lhokseumawe District Police Station

The results of GC analysis of cannabis samples from the Lhokseumawe District police station produced a chromatogram showing 5 (five) peak compounds (Figure 2). The compound peaks resulting from GC analysis of cannabis samples from the Lhokseumawe District Police Station were identified using MS and compared with libraries, the peak compound with RT 3.726 minutes with molecular weight 296 and molecular formula $\mathrm{C} 20 \mathrm{H} 40 \mathrm{O} 3.07 \%$ with Quality99 concluded as Phytol.

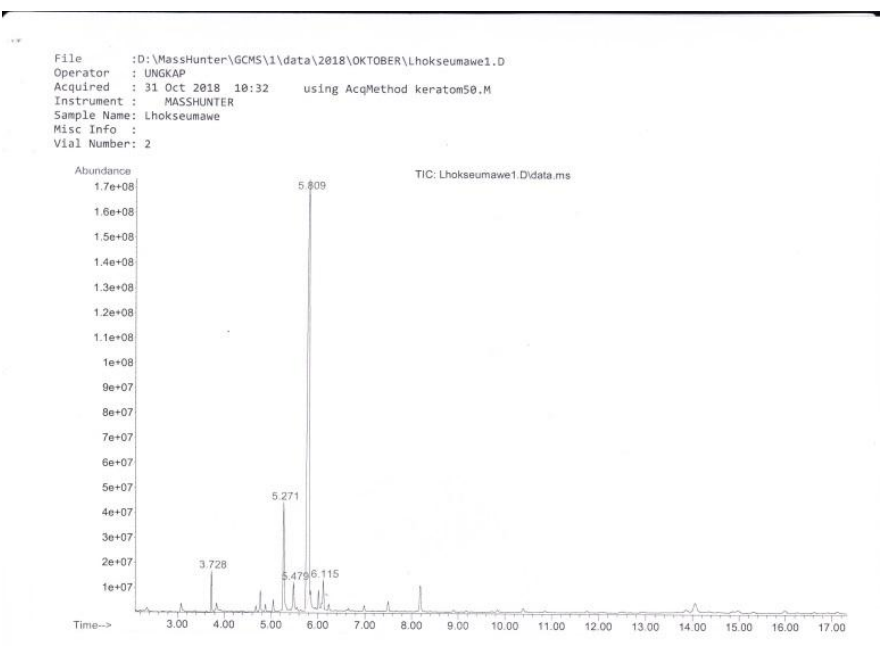

Figure 2. Chromatogram Samples of Marijuana from the Lhokseumawe District Police Station.

The table for the results of GC analysis of cannabis samples from the Lhokseumawe Regional Police Station is shown in the table below. 
TABLE 2. THE CHEMICAL CONTENT OF CANNABIS SAMPLES WAS THE RESULT OF GC-MS ANALYSIS FROM THE LHOKSEUMAWE REGIONAL POLICE STATION.

\begin{tabular}{|c|c|c|c|c|c|c|}
\hline $\begin{array}{c}\text { No } \\
\cdot\end{array}$ & $\begin{array}{c}\text { Retentio } \\
\text { n Time } \\
(\mathrm{RT})\end{array}$ & $\begin{array}{c}\text { Content } \\
(\text { Area } \\
\%)\end{array}$ & $\begin{array}{c}\text { Formula } \\
\text { Molecular }\end{array}$ & $\begin{array}{c}\text { Weight of } \\
\text { Molecular }\end{array}$ & $\begin{array}{c}\text { Chemical } \\
\text { Compounds }\end{array}$ & $\begin{array}{c}\text { Qualit } \\
\mathrm{y}\end{array}$ \\
\hline 1. & 3,728 & 3,07 & $\mathrm{C}_{20} \mathrm{H}_{40} \mathrm{O}$ & 296 & Phytol & 99 \\
\hline 2. & 33,065 & 10,84 & $\mathrm{C}_{21} \mathrm{H}_{30} \mathrm{O}_{2}$ & 314 & $\begin{array}{c}\text { Cannabochro } \\
\text { mene }\end{array}$ & 95 \\
\hline 3. & 34,438 & 2,73 & $\begin{array}{c}\mathrm{C}_{6} \mathrm{H}_{4} \mathrm{~F}_{3} \mathrm{~N}_{3} \\
\mathrm{O}_{2}\end{array}$ & 207 & $\begin{array}{c}\text { 2-Oxo-4- } \\
\text { nitrosometil- } \\
\text { 6-trifluoro- } \\
\text { metil-1,2- } \\
\text { dihidropirimi } \\
\text { din }\end{array}$ & 96 \\
\hline 4 & 35,033 & 80,46 & $\mathrm{C}_{21} \mathrm{H}_{30} \mathrm{O}_{2}$ & 314 & $\begin{array}{c}\text { Delta-9- } \\
\text { Tetrahidrocan } \\
\text { abinol }\end{array}$ & 96 \\
\hline 5. & 35,617 & 2,89 & $\mathrm{C}_{21} \mathrm{H}_{26} \mathrm{O}_{2}$ & 310 & Cannabinol & 98 \\
\hline
\end{tabular}

\section{Results of Marijuana Analysis with GC-MS from the East Aceh Police District}

The results of GC analysis of cannabis samples from the East Aceh District police resulted in a chromatogram showing 5 (five) peaks of compound peak results from GC analysis of marijuana samples from the East Aceh police area identified using MS and compared with libraries with RT 4.824 minutes with molecular weight 286 and formulas the C19H26O2 molecule of $3.28 \%$ with Quality98 was concluded as Delta 9Tetrahidrocannabivarin. With MS spectrum as shown in figure 3.

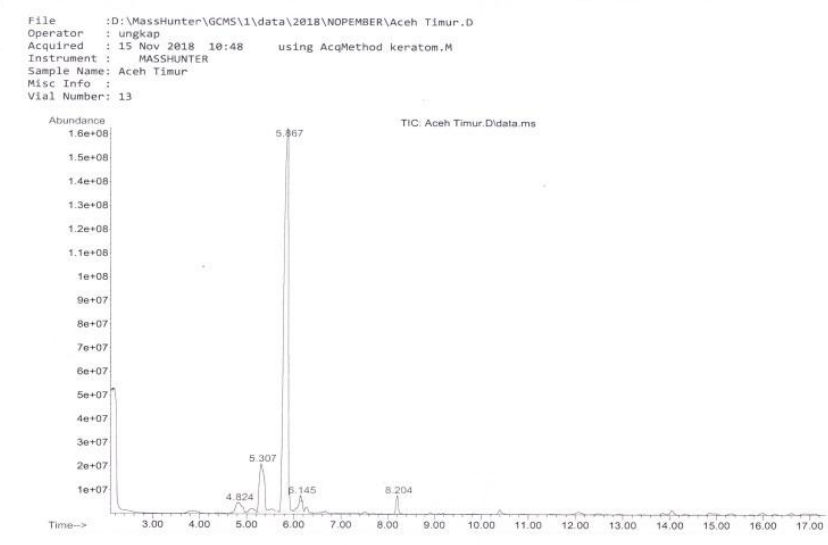

Figure 3. Chromatogram Samples of Marijuana from the East Aceh District Police Station.

The table for the results of GC analysis of cannabis samples from the East Aceh police area is shown in the table below.

\section{TABLE.3. CHEMICAL CONTENT OF CANNABIS SAMPLES FROM GC-MS ANALYSIS FROM THE EAST ACEH DISTRICT POLICE.}

\begin{tabular}{|c|c|c|c|c|c|c|}
\hline $\begin{array}{c}\text { No } \\
\cdot\end{array}$ & $\begin{array}{c}\text { Retentio } \\
\text { n Time } \\
\text { (RT) }\end{array}$ & $\begin{array}{c}\text { Content } \\
(\text { Area } \\
\%)\end{array}$ & $\begin{array}{c}\text { Formula } \\
\text { Molecular }\end{array}$ & $\begin{array}{c}\text { Weight of } \\
\text { Molecular }\end{array}$ & $\begin{array}{c}\text { Chemical } \\
\text { Compounds }\end{array}$ & $\begin{array}{c}\text { Qualit } \\
\mathrm{y}\end{array}$ \\
\hline 1. & 4,837 & 3,28 & $\mathrm{C}_{19} \mathrm{H}_{26} \mathrm{O}_{2}$ & 314 & $\begin{array}{c}\text { Delta 9- } \\
\text { Tetrahidrocan } \\
\text { nabivarin }\end{array}$ & 98 \\
\hline 2. & 5,319 & 10,98 & $\mathrm{C}_{21} \mathrm{H}_{30} \mathrm{O}_{2}$ & 314 & $\begin{array}{c}\text { Cannabicrom } \\
\text { ene }\end{array}$ & 95 \\
\hline 3. & 5,843 & 80,92 & $\mathrm{C}_{21} \mathrm{H}_{30} \mathrm{O}_{2}$ & 314 & Dronabinol & 98 \\
\hline 4. & 6,155 & 2,84 & $\mathrm{C}_{21} \mathrm{H}_{26} \mathrm{O}_{2}$ & 310 & Cannabinol & 99 \\
\hline 5. & 8,194 & 1,98 & $\mathrm{C}_{22} \mathrm{H}_{46}$ & 310 & Docosane & 97 \\
\hline
\end{tabular}

D. The results of the Marijuana Analysis with GC-MS from the area of the Polres Benar Meriah

The results of GC analysis of cannabis samples from the Benar Meriah Police area produced a chromatogram that showed 5 (five) peaks of compounds (Figure 4). The five compound peaks resulting from $\mathrm{GC}$ analysis from cannabis samples from the Benar Meriah area were identified using MS and compared to the library, the compound as RT 4,769 minutes with molecular weight 286 and molecular formula $\mathrm{C} 19 \mathrm{H} 26 \mathrm{O} 24.23 \%$ with Quality91 concluded as $\triangle 9$-THCV [14]. With the MS spectrum as in figure 4, the structure and fragmentation pattern of the compound $\triangle 9-\mathrm{THCV}$ are theoretically shown in Figure 4.

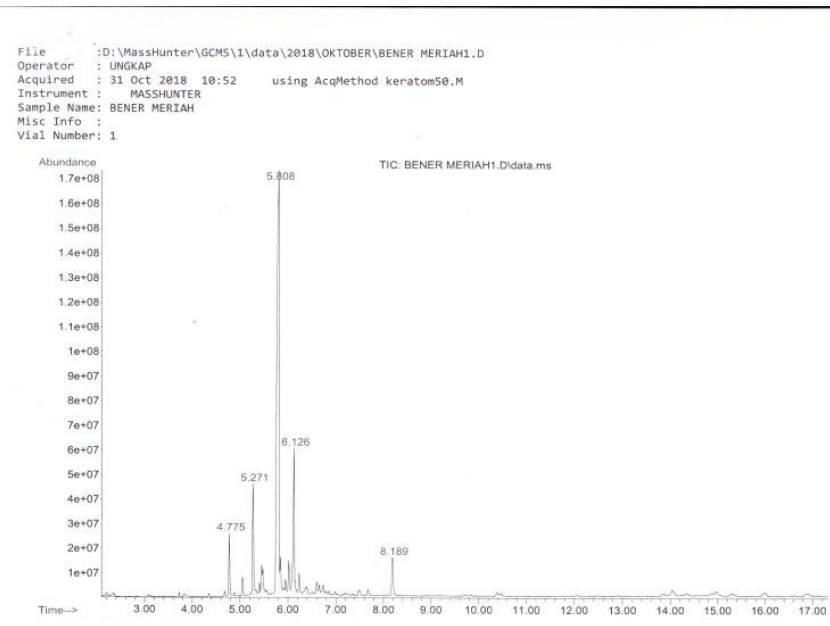

Figure 4. Chromatogram Samples of Marijuana from the Benar Meriah District Police Station.

The table for the results of GC analysis of cannabis samples from the Benar Meriah Police area is shown in the table below.

TABLE 4. THE CHEMICAL CONTENT OF CANNABIS SAMPLES FROM GC-MS ANALYSIS FROM THE REGIONAL POLICE STATION IS BENAR MERIAH.

\begin{tabular}{|l|l|l|l|l|l|l|}
\hline No & Retentio & Content & Formula & Weight of & Chemical & Qualit \\
\hline
\end{tabular}




\begin{tabular}{|c|c|c|c|c|c|c|}
\hline$\cdot$ & $\begin{array}{c}\mathrm{n} \text { Time } \\
\text { (RT) }\end{array}$ & $\begin{array}{c}\text { Area } \\
\%\end{array}$ & Molecular & Molecular & Compounds & $\mathrm{y}$ \\
\hline 1. & 4,769 & 4,23 & $\mathrm{C}_{19} \mathrm{H}_{26} \mathrm{O}_{2}$ & 286 & $\Delta 9-\mathrm{THCV}$ & 91 \\
\hline 2. & $\begin{array}{c}5,288- \\
5,330\end{array}$ & 9,52 & $\mathrm{C}_{21} \mathrm{H}_{30} \mathrm{O}_{2}$ & 314 & $\mathrm{CBC}$ & 95 \\
\hline 3. & 5,786 & 67,93 & $\mathrm{C}_{21} \mathrm{H}_{30} \mathrm{O}_{2}$ & 314 & Dronabinol & 98 \\
\hline 4. & 6,129 & 14,25 & $\mathrm{C}_{21} \mathrm{H}_{26} \mathrm{O}_{2}$ & 310 & CBN & 95 \\
\hline 5. & 8,184 & 4,07 & $\mathrm{C}_{29} \mathrm{H}_{60}$ & 408 & $\begin{array}{c}2 \text { Metil - } \\
\text { Octacosane }\end{array}$ & 99 \\
\hline
\end{tabular}

\section{E. Results of Marijuana Analysis with GC-MS from the Central Aceh Police District (Takengon)}

The results of GC analysis of cannabis samples from the Central Aceh District Police Station (Takengon) produced a chromatogram that showed 4 (four) peak of the compound (Figure 5). The MS spectrum of the Heneic compound provides a spectrum with molecular ion peaks $(\mathrm{M}+)$ at $\mathrm{m} / \mathrm{e}=$ 296 and followed by fragments at $\mathrm{m} / \mathrm{e}=239,141,113,85$ and 57 (figure 5). The structure and fragmentation pattern of the hyeneneane compounds is theoretically shown in Figure 5.

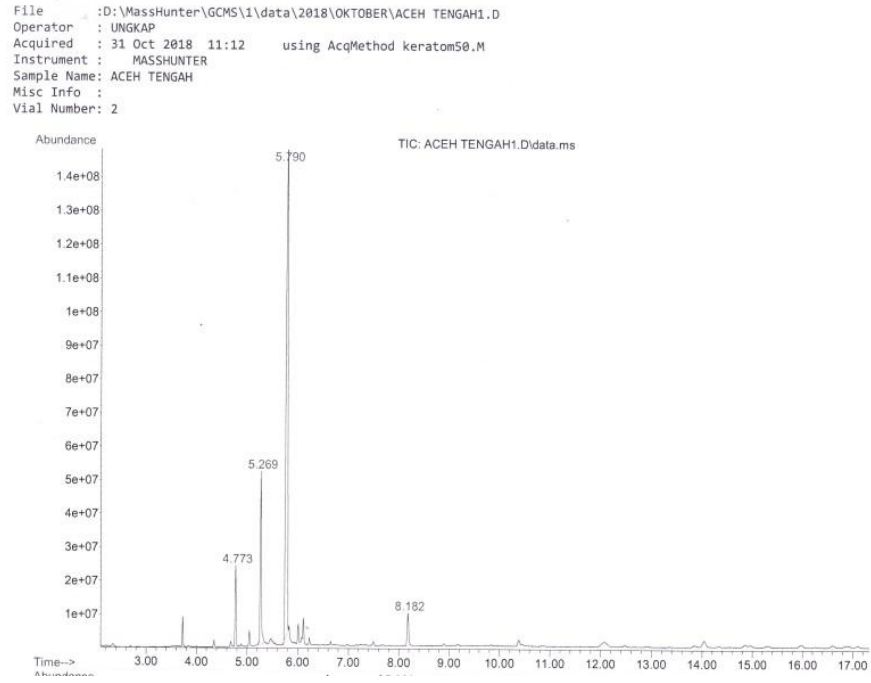

Figure 5. Chromatogram Samples of Marijuana from the Central Aceh District Police Station.

The table for the results of GC analysis of cannabis samples from the Central Aceh Police District (Takengon) is shown in the table below.

TABLE 5. THE CHEMICAL CONTENT OF CANNABIS SAMPLES FROM GC-MS ANALYSIS FROM THE CENTRAL ACEH POLICE STATION (TAKENGON).

\begin{tabular}{|c|c|c|c|c|c|c|}
\hline No & $\begin{array}{c}\text { Retentio } \\
\text { n Time } \\
\text { (RT) }\end{array}$ & $\begin{array}{c}\text { Content } \\
\text { (Area } \\
\% \text { ) }\end{array}$ & $\begin{array}{l}\text { Formula } \\
\text { Molecular }\end{array}$ & $\begin{array}{l}\text { Weight of } \\
\text { Molecular }\end{array}$ & $\begin{array}{l}\text { Chemical } \\
\text { Compounds }\end{array}$ & $\begin{array}{c}\text { Qualit } \\
\mathrm{y}\end{array}$ \\
\hline 1. & 4,769 & 6,08 & $\mathrm{C}_{17} \mathrm{H}_{20} \mathrm{O}_{4}$ & 288 & $\begin{array}{l}\text { 2-Metoxy-5- } \\
\text { isopropilaxy- } \\
7- \\
\text { propenylnaph } \\
\text { thquinone }\end{array}$ & 98 \\
\hline 2. & 5,288 & 16,14 & $\mathrm{C}_{21} \mathrm{H}_{30} \mathrm{O}_{2}$ & 314 & $\begin{array}{c}\text { Cannabichro } \\
\text { me }\end{array}$ & 96 \\
\hline 3. & 5,786 & 73,92 & $\mathrm{C}_{21} \mathrm{H}_{30} \mathrm{O}_{2}$ & 314 & Dronabinol & 98 \\
\hline 4. & 8,178 & 3,86 & $\mathrm{C}_{21} \mathrm{H}_{44}$ & 296 & Heneicosane & 98 \\
\hline $\mathrm{N}$ & Retenti & Conten & Formula & Weight & Chemical & Qual \\
\hline
\end{tabular}

\begin{tabular}{|c|c|c|c|c|c|c|}
\hline o. & $\begin{array}{c}\text { on } \\
\text { Time } \\
(\mathrm{RT})\end{array}$ & $\begin{array}{c}\mathrm{t} \\
(\text { Area } \\
\%)\end{array}$ & $\begin{array}{c}\text { Molecula } \\
\mathrm{r}\end{array}$ & $\begin{array}{c}\text { of } \\
\text { Molecula } \\
\mathrm{r}\end{array}$ & Compounds & ity \\
\hline
\end{tabular}

According to the results of GC-MS analysis, the marijuana sample above from the North Aceh Police Station (Lhokseumawe) shows a specific marker, namely the presence of 2 (two) compounds (Cannabichromene and Phytol) [15]. The marijuana sample from Pidie Police Station (Pidie) showed a specific marker, namely the presence of Dionabinol with the highest percentage of $76.02 \%$. Marijuana samples from the East Aceh police station showed specific markers, namely the presence of Canabicromene and Dionabinol with the highest percentage of $10.98 \%$ and $80.92 \%$. Cannabis samples from the Benar Meriah Police Station showed specific markers namely $\mathrm{CBC}$, Dionabinol and $\mathrm{CBN}$ with the highest percentage of $9.52 \%, 67.93 \%$ and $14.25 \%$ [16] and [17]. The marijuana sample from the Central Aceh Police Station (Takengon) shows a specific marker, namely the presence of the Heneicosane compound.

The variation of the chemical content of the fifth Polis marijuana shows that the composition of the chemical content of each Polres has its own specificity where there are no 2 (two) Polres which contain the exact same chemical composition, as shown in Table 6. For example the composition of the chemical content of Lhokseumawe Police marijuana is not the same as the composition of the chemical content of marijuana from the other 4 (four) Polres.

\section{TABLE 6. CHEMICAL CONTENT OF MARIJUANA FROM 5 (FIVE) POLICE IN THE ACEH REGIONAL POLICE}

\begin{tabular}{|c|c|c|c|c|c|}
\hline $\begin{array}{l}\text { Name of } \\
\text { Compaund }\end{array}$ & $\begin{array}{l}\text { Polre } \\
\text { s } \\
\text { Pidie } \\
(\%)\end{array}$ & $\begin{array}{l}\text { Polres } \\
\text { Loksema } \\
\text { we } \\
(\%)\end{array}$ & $\begin{array}{c}\text { Polres } \\
\text { Aceh } \\
\text { Timur } \\
\text { (Idi } \\
\text { Rayeuk) } \\
(\%)\end{array}$ & $\begin{array}{c}\text { Polres } \\
\text { Benar } \\
\text { Meriah } \\
(\%)\end{array}$ & $\begin{array}{c}\text { Polres } \\
\text { Aceh } \\
\text { Tengah } \\
\text { (Takengo } \\
\text { n) } \\
(\%)\end{array}$ \\
\hline Phytol & - & 3,07 & - & - & - \\
\hline $\begin{array}{l}\text { 2-Metoxy-5- } \\
\text { isopropilaxy-7- } \\
\text { propenylnaphthq } \\
\text { uinone. }\end{array}$ & 6,77 & - & - & - & 6,08 \\
\hline $\begin{array}{c}\text { Cannabichrome } \\
\text { (CBC) }\end{array}$ & 7,70 & 10,84 & 10,98 & - & 16,14 \\
\hline $\begin{array}{c}\text { 2-Oxo-4- } \\
\text { nitrosometil-6- } \\
\text { trifluoro-metil- } \\
1,2- \\
\text { dihidropirimidin }\end{array}$ & - & 2,73 & - & - & - \\
\hline $\begin{array}{c}2 \text { Metil - } \\
\text { Octacosane }\end{array}$ & - & - & - & 4,07 & - \\
\hline Dacosane & - & - & 1,98 & - & - \\
\hline $\begin{array}{l}\text { 1,3- diol, 2-(3,7- } \\
\text { dimetl-2,6- } \\
\text { octadienil) -5- } \\
\text { pentil benzena }\end{array}$ & 2,97 & - & - & - & - \\
\hline Canabinol (CBN) & 2,96 & 2,89 & 2,84 & 14,25 & - \\
\hline $\mathrm{CBC}$ & - & - & & 9,52 & \\
\hline$\triangle 9$-THCV & - & - & 3,28 & 4,23 & \\
\hline Dronabinol $(\Delta 9-$ & 76,0 & 80,48 & 80,92 & 67,93 & 73,92 \\
\hline
\end{tabular}




\begin{tabular}{|c|c|c|c|c|c|}
\hline THC) & 2 & & & & \\
\hline Heneicosane & - & - & - & - & 1,76 \\
\hline
\end{tabular}

\section{CONCLUSION}

From the research on the Analysis of Chemical Content of Cannabis (Cannabis sativa L.) Confiscated in Aceh Police Region by GC-MS Method, this conclusion can be drawn as follows:

1. The main chemical content of cannabis samples from the 5 (five) regions of the Aceh Regional Police using the GCMS instrument, namely marijuana samples from Pidie 2Metoxy-5-isopropilaxy-7-propenylnaphthquinone police 6.77\%; CBC 7.70\%; 1,3-Benzene diol, 2- (3,7-dimethyl2,6-octadienil) -5-pentyl 2,97\%; CBN 2.96\%; and $\Delta 9$-THC $76.02 \%$; marijuana samples from Lhokseumawe police station: $3.07 \%$ Phytol; CBC 10.84\%; CBN 2, $89 \%$; Dronabinol ( $\triangle 9$-THC) $80.48 \%$ and 2-Oxo-4-nitrosomethyl6-trifluoro-methyl-1,2-dihydropyrimidine $\quad 2.73 \%$ marijuana samples from East Aceh District Police (Idi Reyauk): CBC 10.98\%; Dacosane 1.98\%; CBN 2.84\%; $\triangle 9$-THCV 4.23\%; Dronabinol ( $\triangle 9$-THC) $67.93 \%$; marijuana samples from Benar Meriah Police: 2 MethylOctacosane 2.47\%; CBN 14.25\%, CBC 9.52\%; $\triangle 9$-THCV $4.23 \%$ and Dronabinol ( $\triangle 9-\mathrm{THC}) 67.93 \%$; marijuana samples from Central Aceh Police (Takengon); 2-Metoxy5-isopropilaxy-7-propenylnaphth quinone $6.08 \%$; CBC 6.16\%; Dronabinol ( $\triangle 9$-THC) 73.92 and Heneicosane $1.76 \%$.

2. Marijuana samples from 5 (five) different regions in the Aceh Regional Police have a slight difference (0-5\%) between the respective Polres and from all samples containing $\triangle 9$ - THC as the main active constituents.

\section{REFERENCES}

[1] Akiyama, H., K. Fujii., O. Yamasaki., T. Oono., dan K. Iwatsuki. "Antibacterial Action of Several," 2001.

[2] Hafiz EH, Achmad SA, Juliawaty LD, Makmur L, Syah YM, Aimi N, Kitajima M, Takayama H, Ghisalberti EL, "Prenylated Flavonoids and Related Compounds of the Indonesian Artocarpus (Moraceae)," J. Nat Med. 60. 161-184, 2006.
[3] Amrita G, Greeshma N, Deepa M, Poornima EH, “A Review on Anti-Acne Potential of Medicinal Plant Extracts Againts Propionibacterium acnes," International Journal of Pharma and Bio Sciences. 3:988, 2012.

[4] Brooks JS, Butel SA, Morse, "Mikrobiologi Kedokteran," Jakarta: Salemba Medika, 2005.

[5] Bauman, R, "Microbiology," Pearson education, inc, England, 2009.

[6] Cavalieri, S.J., I.D. Rankin., R.J. Harbeck., R.S. Sautter., Y.S McCarter., S.E. Sharp., J.H. Ortez., dan C.A. Spiegel, "Manual of Antimicrobial Susceptibility Testing," 2005, American Society for Microbiology, USA.

[7] Brithis, S.A. and Reinders, R.D., "Antibacterial Activity of Selected Plant Essensial Oils Againts E.Coli," Letters in Appl Microbiology. 58 : 609-615, 2003.

[8] Cowan, M.M, "Plant Products as Antimicrobial Agents," Clinical Microbiology Reviews. 12: 564 - 582, 1999.

[9] Garg A, et al., "Spreading of semisolid formulation," An update, Pharmacetical Technology, 2002.

[10] Lu JB, "The Development of Formula and Quality Control Method for Tranexamic Acid Hydrogel Mask," 2010, Thesis. Department of Applied Chemistry Chaoyang University of Technology. Taiwan. Hal.12-15.

[11] Moffat AL, Lambert PA, "Propionibacerium Acnes," Journal Compilation, 2006, The Society for Applied Microbiology, 42.185-188.

[12] Prakash OMK, Rajesh, Anurag M, Rajiv G, "Artocarpus Heterophyllus (Jackfruit): An Overview," India: Review Article, 2009,3 (6): 353-358.

[13] Hudson, M.H. 1990. The Meechanism of Antioxidants Action In Vitro. Food Antioxidants. Elvesier Aplied Science. London.

[14] Scully C, Cawson RA, "Medical Problems in Dentistry," Churchill Livingstone, 2005, 5 ed. 374.

[15] Todar K Phd, "Staphylococcus aureus and staphylococcal disease," Online textbook of bacteriology, 2008.

[16] Plata K, Rosato AE, Wegrzyn, "Staphylococus Aureus as an Infectious Agent: Overview of Biochemistry and Molecular Genetics of its Pathogenicity," Acta Biochimica Polonica vol 56 (4): 597-612, 2009.

[17] Prakash Om, Jyoit, Kumar A, Kumar P, "Screening of Analgesic and Immunomodulator Activity of Atrocarpus heterophyllus Lam. Leaves (Jackfruit) in Mice,” 2013, ISSN 2278- 4136 Journal of Pharmacognosy and Phytochemistry: 1 (6). 